\title{
STUDIES ON BIOLUMINESCENCE.
}

\section{Chemical Nature of Cypridina Luciferin and Cypridina LUCIFERASE.*}

BX E. NEWTON HARVEY.

(From the Department of Marine Biology, Carnegie Institution of Washington, Washington, and the Physiological Laboratory, Princeton University, Princetom.)

(Received for publication, October 12, 19i8.)

\section{INTRODUCTION.}

In the fourth paper of this series ${ }^{1} \mathrm{I}$ have described the production of light by the ostracod crustacean, Cypridina hilgendorfii, and some of the properties of the photogenic substances found in this animal. Since then I have obtained a large number of Cypridine and have been able to carry out investigation along chemical lines on a far larger scale. This paper deals with the characteristics of two of the photogenic substances, luciferin and luciferase, in more detail. In the seventh paper $^{2}$ reasons are given for the adoption of Dubois' terms, luciferin and luciferase, which in part correspond to my photophelein and photogenin, and I have described how the oxidation product of luciferin, which I have called oxyluciferin, can be reduced to luciferin again. The chemical change involved in the oxidation of luciferin to oxyluciferin appears to be slight and comparable to the change occurring when the leuco-base of a dye is oxidized to the dye itself. It is therefore not surprising to find that oxyluciferin and luciferin have similar properties, and, as far as I have been able to

* Much of this work was performed in the Zoological Laboratory, Imperial University, Tokyo, and I wish to acknowledge the kindness of Professors Ijima, Yatsu, Watase, and Goto during my stay in the University. I am also deeply indebted to Professor Ishikawa of the Agricultural College, Tokyo, for much assistance in collecting material and express my sincere thanks for his interest in the work.

${ }^{1}$ Harvey, E. N., Am.J. Physiol., 1917, xlii, 318.

${ }^{2}$ Harvey, J. Gen. Physiol., 1918, i, 133. 
determine, the properties of oxyluciferin and luciferin are identical, so that what is here recorded regarding luciferin will apply to oxyluciferin also. Unless otherwise specified, luciferin, oxyluciferin, and luciferase refer to these substances obtained from Cypridina hilgendorfii.

\section{Method.}

The living animals are dried quickly in desiccators over $\mathrm{CaCl}_{2}$ and may then be kept indefinitely in well stoppered bottles containing a few lumps of $\mathrm{CaCl}_{2}$ to remove any dampness in the air contained in the bottle. The Cypridina are well ground to a powder which lights brilliantly if moistened with water, both of the photogenic substances going into solution. It serves as the raw material for the isolation of luciferin and luciferase. From this material an extract may be prepared with distilled water which contains luciferin, luciferase, all the proteins of the animal soluble in water, salts, and other water-soluble material. The extract, filtered through filter paper, is yellow colored and slightly opalescent and glows for some time. The light finally disappears due to the oxidation of the luciferin. There is no change of color on standing. If the extract solution is not too concentrated and well shaken with air, all the luciferin will be oxidized and luciferase alone of the photogenic substances together with oxyluciferin will remain. Salts and other crystalloidal substances may be removed by dialysis since luciferase does not dialyze. The solution is remarkably stable. I have allowed it to dialyze against running tap water in a Schleicher and Schüll parchment diffusion thimble for 2 weeks and then against distilled water for 1 more week without any marked loss of luciferase. Indeed, solutions of luciferase may stand until they become foul and ill smelling from bacterial decomposition without destruction of the luciferase. Solution may be preserved free of bacterial development with toluene or chloroform for many months, but a slow destruction of the luciferase occurs and at the same time a precipitate forms. The luciferase is present in the colloidal state as it does not pass collodion or parchment paper membranes. A solution prepared in the above manner will be known as crude luciferase solution. Although the luciferase can be purified by repeated precipitation with a va- 
riety of substances, it loses strength during the process and the crude luciferase solution is the most powerful that can be obtained.

A similar extract may be prepared with hot distilled water which contains one of the photogenic substances, luciferin, all of the proteins of the animal not coagulated by heating, the remaining salts, and other material soluble in hot water. My procedure is to add boiling water directly to the dry powder, boil about 20 seconds, and filter quickly while hot. The filtrate is slightly opalescent, yellow colored, and does not darken on standing. On cooling, this solution often glows faintly but if heated to the boiling point a second time the glow ceases and does not return on cooling. However, its content of luciferin is diminished because some has oxidized to oxyluciferin. This hot water extract of Cypridine will be spoken of as crude luciferin solution. It gives a bright light with luciferase.

If the hot water extract stands in a shallow dish at room temperature, the luciferin disappears completely in the course of some hours, the time depending on its concentration. This is due to oxidation of the luciferin apart from luciferase, as may be easily determined by keeping the luciferin extract in absence of oxygen. I have kept such a solution for 90 days in a test-tube covered with a layer of vaseline 1 inch in depth to prevent access of air, and at the end of that time it was capable of giving a brilliant light when mixed with luciferase. Luciferin and luciferase together in solution are likewise both stable in the absence of oxygen. I have kept such solutions in an evacuated tube or in a hydrogen atmosphere for many months and at the end of that time on admitting air a brilliant light appears.

The oxidative disappearance of luciferin, like other chemical reactions, is greatly accelerated at the higher temperatures. In a previous paper $^{1}$ I called attention to the fact that whereas luciferin was not destroyed by a short boiling, 3 or 4 minutes boiling were sufficient to destroy it. This is entirely a matter of the increased rate of oxidation at the boiling point. We can boil a solution of luciferin without harm for 30 minutes provided the boiling is carried out in a stream of hydrogen which has been rendered free of oxygen by passage over a glowing platinum spiral. Acid retards and alkali favors the oxidation of the luciferin (apart from luciferase). A solution of luciferin made slightly acid with $\mathrm{HCl}$ may be boiled for 25 minutes in the air 
without complete oxidation, whereas a neutral or slightly alkaline solution is quickly oxidized. A solution of luciferin will keep very well in a tall test-tube if the tube is left undisturbed. Diffusion of oxygen into the depths of the tube is very slow. Perhaps the best way to obtain a concentrated solution of luciferin is to filter the hot water extract of Cypridina directly into a tall narrow vessel and pass a current of $\mathrm{CO}_{2}$ through it while cooling. The slight acidity and the anaerobic conditions both prevent oxidation. A little dilute acetic acid may be used in place of carbon dioxide.

Although both luciferin and oxyluciferin will pass collodion or parchment membranes, I have been unable to obtain them in crystalline form, and presume that they also are present in the colloidal state. ${ }^{3}$ The properties of the luciferin in the hot water extract and the luciferase in the cold water extract will be considered under the following heads: Action of enzymes, salting out, alcohol and acetone, solubility in organic solvents, alkaloidal reagents, heavy metal salts, acids and alkalies, adsorbents.

\section{Action of Enzymes.}

Table I gives the results of enzyme experiments. A solution of crude luciferase (or crude luciferin) was mixed with the enzyme preparation and kept at $38^{\circ} \mathrm{C}$. in an incubator for from 18 hours to 4 days. Controls were always employed, using previously boiled enzyme solution. Experiments were also made to determine whether the particular enzyme preparation was active on its substrate, and no experiments were considered in which this was found not to be the case. After the enzyme solution had acted for the proper length of time on the photogenic substances, their light-giving power was tested by adding an equal amount of luciferin (or luciferase) to both control and active tube and comparing the brightness of the light resulting from the active tube with that of the control. In order to prevent oxidation the digests of luciferin were carried out in long test-tubes, full of solution, which were either corked or covered with a

\footnotetext{
${ }^{3}$ Dubois regards Pholas luciferin as a natural albumin and Pholas luciferase as an oxidizing enzyme made up of iron associated with a protein. Dubois, R., La vie et la lumière, Paris, 1914.
} 
thick layer of vaseline. This procedure is not necessary in the case of luciferase.

The salivary diastase was fresh filtered saliva, and the yeast invertase a fresh filtered extract of yeast ground with sand. All the other preparations were made by dissolving the commercial enzyme powder in water. The erepsin was a solution of duodenal scrapings dried in vacuo and powdered, and the spleen, liver, and kidney substance was a solution of these glands dried quickly in vacuo and powdered; all were supplied by the Digestive Ferments Co. of Detroit. The three latter preparations probably contained proteolytic enzymes although they did not digest fibrin under the same conditions with which they were tested with the photogenic substances. The erepsin in neutral solution did not digest fibrin to any extent, or albumen, but tryptophane was produced from Witte's peptone.

Since both acid and alkali injure luciferase and alkali causes a very rapid oxidation of luciferin, some difficulty was experienced in working with pepsin, active only in acid, and with trypsin, most active in alkaline solution. As preparations containing trypsin were found to digest fibrin fairly rapidly in neutral solution, they were made up in water and the experiments show that neutral trypsin solutions will digest luciferase. Presumably such neutral solutions would also digest luciferin if it were capable of digestion, but the results indicate that it is not. Pepsin could only be tested on luciferase with an amount of $\mathrm{HCl}$ lower than the optimum, otherwise the $\mathrm{HCl}$ alone is sufficient to destroy the luciferase. For this reason the action of pepsin was not so carefully investigated, but the result of the one experiment recorded indicates that a slow digestion of luciferase occurs. Acid is not so destructive to luciferin, and 0.2 per cent $\mathrm{HCl}$ plus pepsin was found to possess no digestive power.

It will be noticed from Table I that of all the enzymes tried on luciferase only the proteolytic enzymes have any digestive power. Trypsin, erepsin, and pepsin $\mathrm{HCl}$ all have at least some digestive action. The commercial preparations of pancreas (pancreatin) usually contain some lipase (steapsin) and diastase (amylopsin), but as salivary diastase (ptyalin) and malt diastase did not digest luciferase and a sample of trypsin lacking lipase did digest luciferase, the destructive power of various pancreatin and steapsin preparations is 


\begin{tabular}{|c|c|c|c|c|}
\hline \multirow{3}{*}{ Enzyme solution. } & \multicolumn{4}{|c|}{ Action of enzymes on luciferase, at $38^{\circ} \mathrm{C}$} \\
\hline & \multirow{2}{*}{ Digestive power tested. } & \multirow{2}{*}{$\begin{array}{l}\text { Preserva- } \\
\text { tive. }\end{array}$} & \multicolumn{2}{|r|}{ Light wit } \\
\hline & & & 24 hrs. & 48 hrs. \\
\hline $\begin{array}{l}\text { Malt diastase } * . \ldots \ldots \ldots \\
\text { Same boiled. . . . . . . }\end{array}$ & $\begin{array}{l}\text { Starch digestion. } \\
\text { No digestion. }\end{array}$ & $\begin{array}{l}\text { None. } \\
\text { “ }\end{array}$ & $\begin{array}{l}\text { Brilliant. } \\
\text { “ }\end{array}$ & \\
\hline $\begin{array}{c}\text { Salivary diastase } \ldots \ldots \ldots \ldots \ldots \\
\text { Same boiled. } \ldots \ldots \ldots \ldots \ldots\end{array}$ & $\begin{array}{l}\text { Starch digestion. } \\
\text { No digestion. }\end{array}$ & None. & $\underset{6}{\text { Brilliant. }}$ & \\
\hline $\begin{array}{l}\text { Yeast invertase } \ldots \ldots \ldots \ldots \ldots \\
\text { Same boiled. . . . . . . . . }\end{array}$ & $\underset{" \text { Cane sugar digestion. }}{\text { " }}$ & Toluene. & & \\
\hline 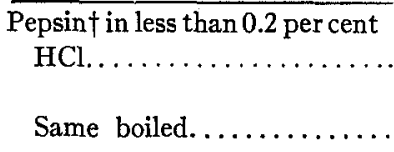 & $\begin{array}{l}\text { Coagulated albumen digestion. } \\
\text { No digestion. }\end{array}$ & $\begin{array}{c}\text { Xylene. } \\
\text { ، }\end{array}$ & $\begin{array}{l}\text { Good. } \\
\text { Brilliant. }\end{array}$ & \\
\hline $\begin{array}{l}\text { Trypsint.......... } \\
\text { Same boiled..... }\end{array}$ & $\begin{array}{l}\text { Fibrin but not olive oil diges- } \\
\text { tion. } \\
\text { No digestion. }\end{array}$ & $\begin{array}{c}\text { Toluene. } \\
\text { “ }\end{array}$ & $\begin{array}{c}\text { Faint. } \\
\text { Brilliant. }\end{array}$ & $\begin{array}{c}\text { Negative. } \\
\text { Bright. }\end{array}$ \\
\hline $\begin{array}{l}\text { Pancreatin } \$ \text { in } 0.5 \text { per cent } \\
\mathrm{Na}_{2} \mathrm{CO}_{3} \ldots \ldots \ldots \ldots \ldots \ldots \ldots \ldots \\
\text { Same boiled } \ldots \ldots \ldots \ldots \ldots \ldots\end{array}$ & $\begin{array}{l}\text { Albumen and starch digestion. } \\
\text { No digestion. }\end{array}$ & $\underset{" \text { Xylene. }}{\text { X }}$ & $\begin{array}{l}\text { Fair. } \\
\text { Brilliant. }\end{array}$ & $\begin{array}{l}\text { Faint. } \\
\text { Brilliant. }\end{array}$ \\
\hline $\begin{array}{l}\text { Pancreatin }{ }^{*} \ldots \ldots \ldots \ldots \ldots \ldots \\
\text { Same boiled. } \ldots \ldots \ldots \ldots \ldots\end{array}$ & $\begin{array}{l}\text { Fibrin and starch digestion. } \\
\text { No digestion. }\end{array}$ & $\underset{*}{\text { Toluene. }}$ & $\begin{array}{l}\text { Negative. } \\
\text { Bright. }\end{array}$ & \\
\hline $\begin{array}{l}\text { Steapsin } \| \ldots \ldots \ldots \ldots \ldots \ldots \\
\quad \text { Same boiled. } \ldots \ldots \ldots \ldots \ldots\end{array}$ & $\begin{array}{l}\text { Fat, fibrin, and starch digestion. } \\
\text { No digestion. }\end{array}$ & Toluene. & $\begin{array}{c}\text { Faint. } \\
\text { Brilliant. }\end{array}$ & $\begin{array}{c}\text { Negative. } \\
\text { Bright. }\end{array}$ \\
\hline 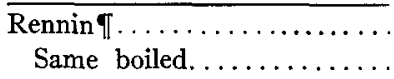 & $\begin{array}{l}\text { Coagulated milk. } \\
\text { No coagulation. }\end{array}$ & $\begin{array}{c}\text { None. } \\
\text { ، }\end{array}$ & $\underset{\text { Bright. }}{\text { is }}$ & \\
\hline $\begin{array}{l}\text { Erepsin } \| \ldots \ldots \ldots \ldots \ldots \\
\text { Same boiled......... }\end{array}$ & $\begin{array}{l}\text { Starch and peptone but not } \\
\text { fibrin or albumen digestion. } \\
\text { No digestion. }\end{array}$ & $\begin{array}{c}\text { Toluene. } \\
\text { " }\end{array}$ & $\begin{array}{l}\text { Fair. } \\
\text { Bright. }\end{array}$ & $\begin{array}{l}\text { Negative. } \\
\text { Bright. }\end{array}$ \\
\hline $\begin{array}{l}\text { Arlco urease............. } \\
\text { Same boiled........ }\end{array}$ & $\begin{array}{l}\text { Urea hydrolyzed. } \\
\text { No action. }\end{array}$ & $\underset{u}{\text { Toluene. }}$ & $\underset{\text { Bright. }}{\text {. }}$ & \\
\hline $\begin{array}{l}\text { Spleen (calf) substancell..... } \\
\text { Same boiled. . . . . . . . . }\end{array}$ & $\begin{array}{l}\text { Olive oil but not fibrin digestion. } \\
\text { No digestion. }\end{array}$ & $\begin{array}{c}\text { Toluene. } \\
\text { " }\end{array}$ & $\begin{array}{l}\text { Good. } \\
\text { Bright. }\end{array}$ & $\begin{array}{l}\text { Faint. } \\
\text { Bright. }\end{array}$ \\
\hline $\begin{array}{c}\overline{\text { Kidney (beef) substance } \| . . \ldots \ldots} \\
\text { Same boiled.............. }\end{array}$ & $\begin{array}{l}\text { Fibrin or oil not digested. } \\
\text { No digestion. }\end{array}$ & $\underset{\text { Toluene. }}{\text {. }}$ & Good. & Fair. \\
\hline $\begin{array}{l}\text { Liver (hog) substance } \| . . \\
\text { Same boiled. ......... }\end{array}$ & $\begin{array}{l}\text { Olive oil but not fibrin di- } \\
\text { gestion. } \\
\text { No digestion. }\end{array}$ & $\begin{array}{c}\text { Toluene. } \\
\text { a }\end{array}$ & $\begin{array}{l}\text { Good. } \\
\text { Bright. }\end{array}$ & $\begin{array}{l}\text { Faint. } \\
\text { Bright. }\end{array}$ \\
\hline
\end{tabular}

* Merck. † Merck, U. S. P. $\ddagger$ Fairchild, Bros. and Foster. 


\begin{tabular}{|c|c|c|c|c|c|c|c|}
\hline \multicolumn{3}{|c|}{ water (unless stated otherwise). } & \multicolumn{5}{|c|}{ Action of enzymes on luciferin at $38^{\circ} \mathrm{C}$. kept in absence of oxygen. } \\
\hline \multicolumn{2}{|l|}{ Iciferin after } & \multirow{2}{*}{ Remarks. } & \multirow{2}{*}{$\begin{array}{l}\text { Preserva- } \\
\text { tive. }\end{array}$} & \multicolumn{3}{|c|}{ Light with luciferase after } & \multirow{2}{*}{ Remarks. } \\
\hline 72 hrs. & $96 \mathrm{hrs}$. & & & 18 hrs. & 24 hrs. & 48 hrs. & \\
\hline & & & $\begin{array}{l}\text { None. } \\
\text { ، }\end{array}$ & $\underset{\text { Good. }}{ }$ & & & \\
\hline & & & None. & & & Good. & $\begin{array}{l}\text { Repeated with } \\
\text { same result. }\end{array}$ \\
\hline$\underset{\text { Bright. }}{\text { B }}$ & & $\begin{array}{l}\text { Repeated twice } \\
\text { with same re- } \\
\text { sult. }\end{array}$ & None. & & $\begin{array}{l}\text { Good. } \\
\text { Fair. }\end{array}$ & & \\
\hline \multirow[t]{7}{*}{$\begin{array}{c}\text { Good. } \\
\text { Brilliant. }\end{array}$} & & & & $\begin{array}{l}\text { Fair. } \\
\text { “ }\end{array}$ & & & $\begin{array}{l}\text { Solution neutral- } \\
\text { ized before test- } \\
\text { ing. } \\
0.2 \text { per cent } \mathrm{HCl} \\
\text { used. }\end{array}$ \\
\hline & $\begin{array}{l}\text { Faint. } \\
\text { Brilliant. }\end{array}$ & $\begin{array}{l}\text { Luciferase concen- } \\
\text { trated. } \\
\text { Repeated twice } \\
\text { with neutral } \\
\text { pancreatin and } \\
\text { same result. }\end{array}$ & $\underset{\text { Toluene. }}{\text { Ta }}$ & & & $\underset{\sim}{\text { Bright. }}$ & $\begin{array}{l}\text { Neutral pancre- } \\
\text { atin used. }\end{array}$ \\
\hline & & & Toluene. & & & Bright. & \\
\hline & & $\begin{array}{l}\text { Note that this so- } \\
\text { lution contains } \\
\text { trypsin. }\end{array}$ & Toluene. & & & Bright. & $\begin{array}{l}\text { Repeated twice; } \\
\text { same result. }\end{array}$ \\
\hline & & & None. & $\underset{" \text { Fair. }}{ }$ & & & \\
\hline & & $\begin{array}{l}\text { Repeated with } \\
\text { same result. }\end{array}$ & $\begin{array}{c}\text { Toluene. } \\
\text { a }\end{array}$ & & & $\begin{array}{c}\text { Bright. } \\
\text { " }\end{array}$ & $\begin{array}{l}\text { Repeated twice; } \\
\text { same result. }\end{array}$ \\
\hline & & & None. & Good. & & & \\
\hline $\begin{array}{l}\text { Very faint. } \\
\text { Bright. }\end{array}$ & $\begin{array}{l}\text { Negative. } \\
\text { Bright. }\end{array}$ & & None. & & Good. & & \\
\hline Fair. & Fair. & & None. & & Good. & & \\
\hline Faint. & Negative. & & None. & & Good. & & \\
\hline Bright. & Bright. & & “ & & " & & \\
\hline
\end{tabular}

§ Parke Davis Co. \|Digestive Ferments Co. I Chr. Hansen. 
unquestionably due to their trypsin content. That the destruction of luciferase is actually due to digestion and not to the injurious action of amino-acids resulting from the digestion of proteins associated with the luciferase is shown by adding the products of a 4 day (at $38^{\circ} \mathrm{C}$.) tryptic digest of albumen (then boiled to destroy the trypsin) to luciferase, and keeping the mixture with toluene at $38^{\circ} \mathrm{C}$. for 4 days more. The luciferase was found to be unaffected by the aminoacids present.

These experiments all indicate that luciferase is a protein. As erepsin has a digestive action one might suppose that it belongs to the group of proteoses, but too great reliance cannot be placed on conclusions drawn from the action of erepsin, as this enzyme is said to hydrolyze histones, protamines, casein, fibrin, and nucleic acid in addition to proteoses and peptones. ${ }^{4}$ Dubois finds that Pholas luciferase is digested by trypsin. ${ }^{5}$

On the other hand, none of the enzyme preparations tested had any action on luciferin. The proteolytic enzymes especially were studied with great care and with the result that no digestive action could be demonstrated. In one experiment not recorded in Table I luciferin was mixed with a Parke Davis Co. pancreatin preparation, having active proteolytic power and kept at $38^{\circ}$ for 4 days without digesting the luciferin. Erepsin also had no digestive action after 4 days at $38^{\circ}$. Merck's pancreatin (without toluene) had no digestive action after 8 days at $38^{\circ} \mathrm{C}$. Dried powdered Cypridine were mixed with Merck's pancreatin and toluene and kept at $38^{\circ} \mathrm{C}$. for 8 days. This digest was found to contain no luciferase but abundant luciferin. There is no doubt of the non-digestibility of the latter. As already mentioned, these digests must be carried out in absence of oxygen, otherwise the luciferin undergoes spontaneous oxidation to oxyluciferin and disappears apart from any enzyme action. The oxyluciferin like luciferin itself is also undigested after 4 days action of a pancreatin solution at $38^{\circ} \mathrm{C}$. As all common proteins, except the racemized proteins and certain very insoluble albuminoides (elastin

${ }^{4}$ Samuely, F., in Oppenheimer, C., Handb. Biochem. des Menschen und der Tiere, Jena, 1909, i, 554.

${ }^{5}$ Dubois, R., Ann. Soc. Linn. Lyons, 1914, xli, 161. 
and keratin), are digested by trypsin, these experiments indicate that luciferin is not a common protein, but they give us no idea of the class to which it belongs.

\section{Salting Out.}

If crude luciferase solution is saturated with crystals of $\mathrm{NaCl}$ at $20^{\circ} \mathrm{C}$. no precipitate forms but only a slight turbidity appears. The solution filters turbid and luciferase is found unharmed in the filtrate. Saturation with $\mathrm{NaCl}$ is a good method of preserving luciferase from the growth of moulds and bacteria.

One-half saturation with $\mathrm{MgSO}_{4}$ also produces a slight turbidity and luciferase is found unharmed in the filtrate. Complete saturation with $\mathrm{MgSO}_{4}$ produces a fine precipitate, again dissolving in water, which contains considerable luciferase. The opalescent filtrate also contains some luciferase so that saturated $\mathrm{MgSO}_{4}$ precipitates luciferase partially but not completely.

One-half saturation with $\left(\mathrm{NH}_{4}\right)_{2} \mathrm{SO}_{4}$ produces a precipitate which contains very little luciferase after washing with half saturated $\left(\mathrm{NH}_{4}\right)_{2} \mathrm{SO}_{4}$. Most of the luciferase is found in the filtrate. On saturation with $\left(\mathrm{NH}_{4}\right)_{2} \mathrm{SO}_{4}$ an abundant precipitate forms and $n o$ luciferase remains in the filtrate. The $\left(\mathrm{NH}_{4}\right)_{2} \mathrm{SO}_{4}$ precipitate dissolves completely in water and gives a brilliant light if mixed with Iuciferin.

If a crude solution of luciferin is saturated with $\mathrm{NaCl}$ or half saturated with $\mathrm{MgSO}_{4}$ or half saturated with $\left(\mathrm{NH}_{4}\right)_{2} \mathrm{SO}_{4}$ no precipitate forms. The luciferin remains in solution. With saturated $\mathrm{MgSO}_{4}$ the luciferin is partially precipitated; with saturated $\left(\mathrm{NH}_{4}\right)_{2} \mathrm{SO}_{4}$ it is almost completely precipitated, but a small amount of luciferin still remains in the filtrate. The addition of acetic acid to the point where precipitation of the crude luciferin solution is complete (probably a nucleoprotein or mucin is precipitated) and subsequent careful saturation with $\mathrm{MgSO}_{4}$ or $\left(\mathrm{NH}_{4}\right)_{2} \mathrm{SO}_{4}$ does not completely precipitate the luciferin.

The above results can be confirmed by adding saturated solutions of $\mathrm{NaCl}$ or $\mathrm{MgSO}_{4}$ or $\left(\mathrm{NH}_{4}\right)_{2} \mathrm{SO}_{4}$ to dry powdered Cypridina. The powder glows strongly in saturated $\mathrm{NaCl}$ which dissolves both lucif- 
TABLE II.

Properties of Photogenic Substances.

\begin{tabular}{|c|c|c|c|}
\hline \multicolumn{2}{|r|}{ Property. } & Luciferase. & Luciferin. \\
\hline $\begin{array}{r}\text { Salting } \\
\text { out by }\end{array}$ & 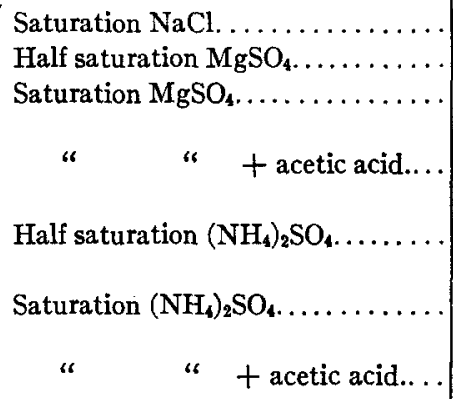 & $\begin{array}{l}\text { Not precipitated. } \\
\text { “6 } \\
\text { Nearly completely } \\
\text { precipitated. } \\
\text { Slightly precipi- } \\
\text { tated. } \\
\text { Completely pre- } \\
\text { cipitated. }\end{array}$ & $\begin{array}{l}\text { Not precipitated. } \\
\text { " } \\
\text { Partially precipi- } \\
\text { tated. } \\
\text { " } \\
\text { Not precipitated. } \\
\text { Nearly completely } \\
\text { precipitated. } \\
\text { " " }\end{array}$ \\
\hline $\begin{array}{l}\text { Solubility } \\
\text { in }\end{array}$ & 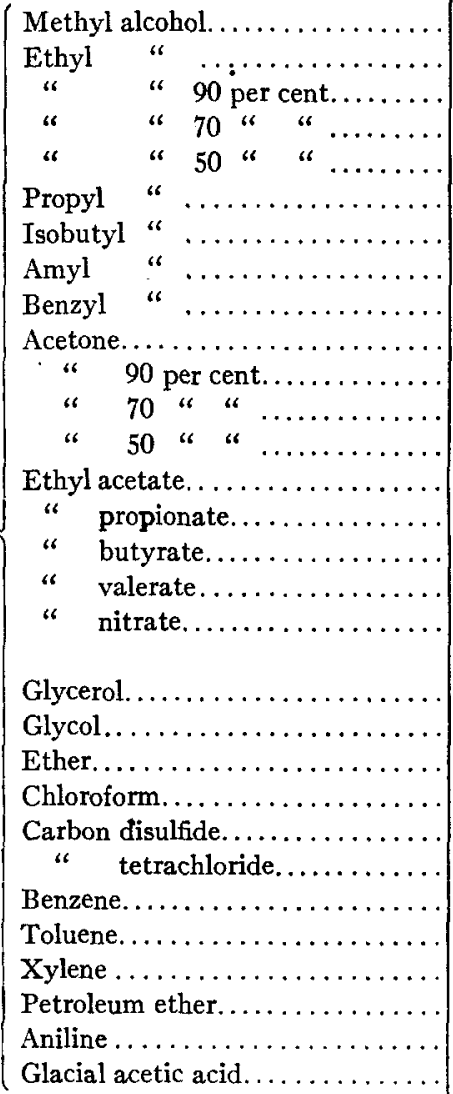 & $\begin{array}{c}\text { Insoluble. } \\
\text { " } \\
\text { " } \\
\text { Slightly soluble. } \\
\text { Insoluble. } \\
\text { " } \\
\text { " } \\
\text { " } \\
\text { " } \\
\text { " } \\
\text { Slightly soluble. } \\
\text { Fairly soluble. } \\
\text { Insoluble. } \\
\text { " } \\
\text { " } \\
\text { " } \\
\text { " } \\
\text { " } \\
\text { " } \\
\text { " } \\
\text { " } \\
\text { " } \\
\text { " } \\
\text { " }\end{array}$ & $\begin{array}{c}\text { Soluble. } \\
\text { " } \\
\text { " } \\
\text { " } \\
\text { " } \\
\text { Fairly soluble. } \\
\text { Slightly " } \\
\text { Soluble. } \\
\text { Fairly soluble. } \\
\text { Soluble. } \\
\text { " } \\
\text { " } \\
\text { " } \\
\text { Fairly soluble. } \\
\text { " } \\
\text { Slightly " } \\
\text { Very slightly sol- } \\
\text { uble. } \\
\text { Soluble. } \\
\text { " } \\
\text { Insoluble. } \\
\text { " " } \\
\text { " } \\
\text { " } \\
\text { " } \\
\text { Fairly soluble. } \\
\text { " } \\
\text { " }\end{array}$ \\
\hline
\end{tabular}


erin and luciferase; weakly, in saturated $\mathrm{MgSO}_{4}$ which dissolves some luciferin but very little luciferase; and not at all in saturated $\left(\mathrm{NH}_{4}\right)_{2} \mathrm{SO}_{4}$ which dissolves no luciferase. On filtering the saturated $\left(\mathrm{NH}_{4}\right)_{2} \mathrm{SO}_{4}$ extract of dry Cypridine and pouring this into water, no light appears, but if luciferase is now added, a faint light appears, showing that a small amount of luciferin has gone into solution. These results are summarized in Table II.

Although we ordinarily think of the proteins as the substances, par excellence, capable of being salted out of solution, the property is characteristic of many emulsion colloids, notably soaps, polysaccharides, and phospholipins. However, neither luciferase nor luciferin is a soap because they are not precipitated by $\mathrm{CaCl}_{2}$; nor phospho- or galactolipins, because they are both insoluble in ether and benzene, hot or cold. It is possible that they are of polysaccharide nature as starch. and glycogen are nearly if not completely precipitated by saturating their solution with $\left(\mathrm{NH}_{4}\right)_{2} \mathrm{SO}_{4}$. But the polysaccharides are not precipitated by phosphotungstic acid, whereas luciferase is completely precipitated and luciferin very nearly completely precipitated (see p. 283).

The evidence from salting out experiments indicates that both luciferin and luciferase are proteins, the former on the border-line between proteoses and peptones, the latter a more complicated protein but not a globulin. Dubois ${ }^{5}$ finds Pholas luciferin completely precipitated by saturation with $\left(\mathrm{NH}_{4}\right)_{2} \mathrm{SO}_{4}$ but not by $\mathrm{MgSO}_{4}$ or $\mathrm{NaCl}$.

\section{Alcohol and Acetone.}

If strong ethyl alcohol or acetone is added to a solution of crude luciferase, an abundant precipitate forms. This precipitate is found to contain the luciferase which is separated completely from solution by alcohol between 50 and 60 per cent, and by acetone between 70 and 80 per cent. We are dealing in both cases with a precipitation and not a coagulation of luciferase. The precipitates partially redissolve in water and if the solution is filtered luciferase is found in the filtrate. Indeed, the precipitates from addition of alcohol or acetone to crude luciferase may stand under alcohol (95 per cent) or acetone ( 90 per cent) respectively for 35 days without complete de- 
struction of the luciferase, but there is always a diminution of activity which is no doubt eventually complete. The alcohol or acetone precipitate may be washed and dried and will give light whenever luciferin is added.

If strong ethyl alcohol or acetone is added to a solution of crude luciferin, a precipitate also forms, but it is not nearly so voluminous, since the heat-coagulable proteins are absent from the luciferin solution. With alcohol the precipitate is very fine; with acetone it is flocculent and clumps together readily. The precipitates washed once with 95 per cent alcohol and acetone respectively dissolve completely in water but these solutions give only a faint or no light if luciferase is added. On the other hand, the filtered alcohol and acetone solutions contain considerable amounts of luciferin. The absence of luciferin in the alcohol and acetone precipitates is only apparent. It is really partly precipitated by alcohol and acetone but is largely oxidized during the process of testing. Experiments indicate that oxyluciferin is present in the precipitates and can be reconverted into luciferin by appropriate methods. These experiments indicate that alcohol and acetone only partially precipitate luciferin, but completely precipitate luciferase. Boiling absolute alcohol will extract a considerable amount of luciferin and such a solution is quite stable even if exposed to air provided the alcohol is not allowed to evaporate. In alcohol-water and acetone-water mixtures the luciferin oxidizes readily and disappears in the course of a day or so.

\section{Solubility in Organic Solvents.}

The solubility of luciferin and luciferase in a number of pure organic solvents was tested by extracting the dried powdered $C y p r i d i n \in$, filtering, and then testing the filtrate by the addition of luciferase and luciferin, respectively. Small pieces of the photogenic gland will sometimes pass through ordinary filter paper, but can always be recognized as isolated brightly luminous dots appearing when the solvent is tested for photogenic material. A heavy blotting paper holds back these fine particles and was used for filtering except in the case of very viscous solvents. The results are summarized in Table II.

It will be noticed that luciferase is not extracted by any of the solvents tried, whereas luciferin is soluble in a considerable number of 
them. Methyl alcohol, ethyl alcohol, propyl alcohol, benzyl alcohol, ethyl acetate, glycerol, and glycol all dissolve a considerable amount of luciferin. Solvents non-miscible with water, such as benzyl alcohol or ethyl acetate, give up their content of luciferin to the water phase and it then luminesces if luciferase is present. In the case of the homologous series of aliphatic alcohols, the higher the alcohol in the series the less luciferin will it dissolve. The same is true for the homologous series of esters.

Luciferin is fairly stable in methyl alcohol, ethyl alcohol, propyl alcohol, benzyl alcohol, and glycerol if no water is present, but rather quickly disappears in acetone, glycol, and ethyl acetate, presumably because oxidation occurs more rapidly in the latter solvents. In the typical fat solvents as ether, chloroform, benzene, etc., the luciferin is insoluble. Luciferin is also soluble in glacial acetic acid but not in aniline.

There is nothing in the solubility relations of luciferase to indicate that it is not a protein. On the other hand, the solubilities of luciferin are certainly unusual for a natural protein. The best known class of proteins soluble in alcohol is the protamines of plants, but the protamines are insoluble in water and absolute alcohol. Zein, the protamine of corn, is soluble in 90 per cent ethyl alcohol, methyl and propyl alcohols, glycerol heated to $150^{\circ} \mathrm{C}$., and glacial acetic acid. ${ }^{6}$ Recently Osborne and Wakeman ${ }^{7}$ have described a protein from milk having solubilities similar to those of gliadin, the protamine of wheat. Welker ${ }^{8}$ has described a substance, obtained from Witte's peptone giving the biuret, Millon, and Hopkins-Cole tests, which is soluble in water and absolute alcohol but not in ether, and it is possible that others of the peptones are soluble in absolute alcohol. On. the other hand, some proteins in the absence of salts form colloidal solutions in strong alcohol from which they may be precipitated by an appropriate salt. ${ }^{2}$ As the absolute alcohol extract of $C y p r i d i n c e$ was made from dry material containing the salts of sea water, some salt was present, but there is always the possibility of sol formation.

${ }^{6}$ Osborne, T. B., Ergebn. Physiol., 1910, x, 47.

${ }^{7}$ Osborne, T. B., and Wakeman, A. J., J. Biol. Chem., 1918, xxxiii, 243.

${ }^{8}$ Welker, W. H., Biochem. Bull., 1912-13, ii, 70.

${ }^{9}$ Private communication from T. B. Osborne. 
If we extract dried Cypridina, which have previously been thoroughly extracted with benzene, with $800 \mathrm{cc}$. of boiling absolute alcohol for an hour, filter the alcohol extract through blotting paper and hardened filter paper, quickly evaporate the filtrate to dryness on the water bath, and dissolve the residue in a small quantity of water saturated with $\mathrm{CO}_{2}$, we obtain a yellow opalescent solution which gives a bright light with luciferase. This solution contains some protein or protein derivatives as it gives a very faint Millon reaction, a good positive ninhydrin test, reddish blue in color, but no biuret reaction. It precipitates with tannic and phosphotungstic acids but not with picric, acetic, trichloroacetic, or chromic acids or on saturation with $\left(\mathrm{NH}_{4}\right)_{2} \mathrm{SO}_{4}$. The phosphotungstic precipitate is not due to the presence of calcium. The extract gives a faint Molisch reaction for carbohydrates. As the evidence points to the presence of some protein material in the absolute alcohol extract of Cypridince, it is possible that this protein is luciferin. It should be emphasized, however, that the Millon reaction was very faint although the ninhydrin was quite marked.

\section{Alkaloidal Reagents.}

A solution of phosphotungstic acid added to crude luciferase solution gives a voluminous precipitate which, if washed quickly in running water on the filter and then suspended in water, does not completely dissolve but gives a good light if luciferin is added. It dissolves if a trace of dilute $\mathrm{NH}_{4} \mathrm{OH}$ solution is added. The filtrate gives no light with excess luciferin, even though it contains some material which will precipitate on addition of more phosphotungstic acid.

Tannic acid added in slight excess to luciferase gives an abundant precipitate which contains luciferase and will give a good light with luciferin if suspended in water. It does not completely dissolve, even on addition of dilute $\mathrm{NH}_{4} \mathrm{OH}$ solution. The filtrate gives a very faint light on addition of an excess of luciferin, even though an excess of tannic acid was used to precipitate and all precipitable material was thrown down.

Saturated aqueous picric acid added in equal volume to crude luciferase solution gives a not very abundant precipitate which if 
filtered off, washed quickly with water, and suspended in water, does not completely dissolve. If luciferin is added the precipitate does dissolve and a good light appears. Dilute $\mathrm{NH}_{4} \mathrm{OH}$ solution causes the precipitate to dissolve. The filtrate gives a very faint light when an excess of luciferin is added, even though everything was precipitated that would precipitate with picric acid and an excess of the latter was present. The excess of picric acid was not sufficient to harm the luciferin used in testing.

Luciferase is, therefore, completely precipitated by phosphotungstic acid and almost completely precipitated by tannic and picric acids without harm.

Phosphotungstic acid added to a solution of crude luciferin to slight excess gives a bulky precipitate which can be filtered off and the filtrate is perfectly clear. It gives no further precipitate with phosphotungstic acid but contains a small amount of luciferin, as a faint light appears when luciferase in excess (since luciferase is also precipitated by the excess phosphotungstic acid present) is added. The precipitate washed on the filter with dilute phosphotungstic acid does not dissolve completely in water but partly dissolves forming an opalescent solution. It is brought into solution by adding crude luciferase or a trace of dilute $\mathrm{NH}_{4} \mathrm{OH}$ solution. The precipitate contains luciferin and gives a brilliant light with luciferase. It is probably the slight alkalinity of the luciferase solution which causes resolution of the luciferin precipitate. The addition of a small amount of $\mathrm{HCl}$ to the phosphotungstic-luciferin filtrate causes further precipitation, leaving a clear supernatant fluid containing no trace of luciferin.

Tannic acid likewise gives a voluminous precipitate with luciferin solutions and the filtrate is clear at first but may become cloudy in a short time, especially at the surface, unless considerable tannic acid is added. If an excess of tannic acid is present, as indicated by absence of further precipitate on adding more tannic acid, a small amount of luciferin is present in the filtrate but practically all is precipitated. The precipitate does not completely dissolve in water even if $\mathrm{NH}_{4} \mathrm{OH}$ is added, but gives a bright light when luciferase is added. The addition of a small amount of acetic acid $+\mathrm{NaCl}$ or $\mathrm{HCl}$ does not cause further precipitation. Both the phosphotungstic 
and tannic acid precipitates can be dried and will again give light with luciferase if redissolved.

TABLE III.

Properties of Photogenic Substances.

\begin{tabular}{|c|c|c|c|}
\hline & Property. & Luciferase. & Luciferin. \\
\hline $\begin{array}{r}\text { Alkaloidal } \\
\text { reagents }\end{array}$ & 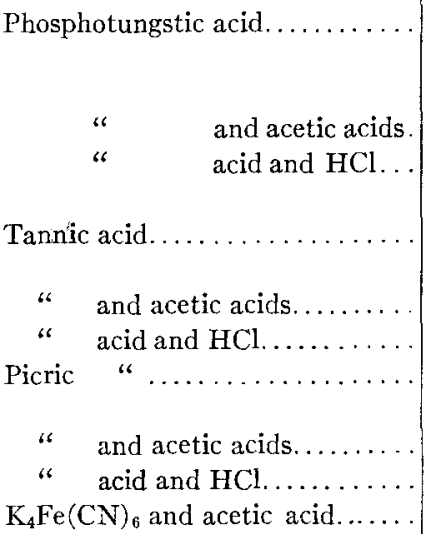 & $\begin{array}{l}\text { Nearly completely } \\
\text { precipitated. }\end{array}$ & $\begin{array}{l}\text { Very nearly com- } \\
\text { pletely precipi- } \\
\text { tated. " } \\
\text { " " } \\
\text { Completely precipi- } \\
\text { tated. } \\
\text { Nearly completely } \\
\text { precipitated. } \\
\text { " " " " } \\
\text { " Not precipitated. } \\
\text { " " } " \\
\text { " }\end{array}$ \\
\hline $\begin{array}{l}\text { Heavy metal } \\
\text { salts }\end{array}$ & 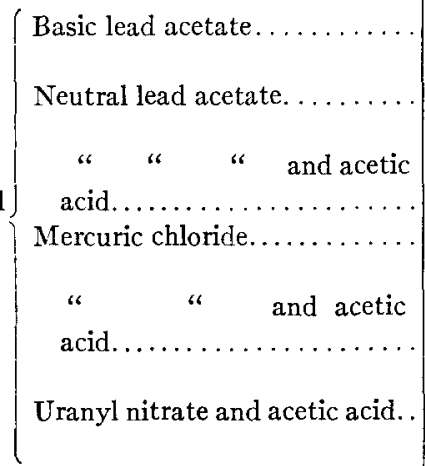 & $\begin{array}{l}\text { Completely pre- } \\
\text { cipitated. } \\
\text { Nearly completely } \\
\text { precipitated. }\end{array}$ & $\begin{array}{l}\text { Not completely } \\
\text { precipitated. } \\
\text { ، } \\
\text { Not precipitated. } \\
\text { Not completely } \\
\text { precipitated. } \\
\text { Almost completely } \\
\text { precipitated. } \\
\text { Not completely } \\
\text { precipitated. }\end{array}$ \\
\hline $\begin{array}{r}\text { Acids and } \\
\text { alkalies }\end{array}$ & $\begin{array}{l}\mathrm{NaOH} \ldots \ldots \ldots \ldots \\
\mathrm{NH}_{4} \mathrm{OH} \ldots \ldots \ldots \ldots \\
\text { Acetic acid } \ldots \ldots \ldots \ldots \\
\mathrm{H}_{2} \mathrm{CO}_{3} \ldots \ldots \ldots \ldots \ldots \\
\text { Trichloroacetic acid. }\end{array}$ & $\begin{array}{c}\text { Not precipitated. } \\
\text { "6 } \\
\text { " } \\
\text { " } \\
\text { " }\end{array}$ & $\begin{array}{c}\text { Not precipitated. } \\
\text { " } \\
\text { " } \\
\text { " } \\
\text { " }\end{array}$ \\
\hline
\end{tabular}

Picric acid added to luciferin solution gives no good precipitate but only an opalescence or turbidity. This is true even when picric acid 
is present in considerable excess, as on addition of an equal volume of saturated aqueous picric acid. Further addition of a little dilute acetic acid or $\mathrm{HCl}$ does not cause precipitation. The solution filters turbid and luciferin may be demonstrated in the filtrate on adding luciferase. A yellow light due to the picric acid in solution appears. A little dilute $\mathrm{NH}_{4} \mathrm{OH}$ clears the turbidity.

If we add acetic acid to luciferin solution until the precipitation (probably a precipitate of mucin and nucleoprotein) is complete and then dilute $\mathrm{K}_{4} \mathrm{Fe}(\mathrm{CN})_{6}$ solution, no further precipitate forms and luciferin is found abundantly in the filtrate which gives no further precipitate with $\mathrm{K}_{4} \mathrm{Fe}(\mathrm{CN})_{6}$ and acetic acid. These results are recorded in Table III.

Luciferin is, therefore, very nearly completely precipitated by phosphotungstic and taninic acids but not by picric acid. It is completely precipitated unharmed by phosphotungstic acid $+\mathrm{HCl}$, but not by tannic acid $+\mathrm{HCl}$ or picric acid $+\mathrm{HCl}$. It is not precipitated by potassium ferrocyanide and acetic acid. Dubois ${ }^{10}$ finds Pholas luciferin to be completely precipitated by picric acid.

\section{Heavy Metal Salts.}

Some of the heavy metal salts ( $\mathrm{Pb}$ acetate, $\left.\mathrm{AgNO}_{3}, \mathrm{CuSO}_{4}\right)$ precipitate in sea water. As both crude luciferin and luciferase solutions, although prepared with distilled water, contain small amounts of the salts of sea water, a slight precipitate would be formed upon addition of lead acetate. It is too small in amount to interfere with the action of lead acetate as a precipitant, but it must be borne in mind that some of the luciferin or luciferase might be adsorbed on any precipitate formed, as this is especially likely to occur with inorganic precipitates. Another difficulty encountered in precipitating protein solutions with heavy metal salts is that in excess of heavy metal salt some of the precipitate may redissolve. However, certain definite results were obtained by precipitating crude luciferin and luciferase with lead and mercury salts (the usual protein precipitants) and these are described below although their interpretation may be open to question.

${ }^{10}$ Dubois, Ann. Soc. Linn. Lyons, 1913, lx. 
Neutral lead acetate solution was added to crude luciferase solution, drop by drop, until no further precipitate formed. The filtrate was clear and gave no further precipitate on adding more lead acetate. It gave a good light with excess of luciferin. The precipitate suspended in water does not dissolve, but upon addition of luciferin gives a bright light.

Basic lead acetate added drop by drop gives a bulky precipitate leaving a clear filtrate which gives no further precipitate on addition of more basic lead acetate. This filtrate gives no light with excess luciferin but the precipitate washed once with water on the filter gives a bright light.

Saturated $\mathrm{HgCl}_{2}$ solution was added drop by drop to luciferase solution until no further precipitate occurs. The filtrate is perfectly clear and gives a bright light with luciferin although it gives no further precipitate with $\mathrm{HgCl}_{2}$. The precipitate washed on the filter for 20 hours in running water is suspended in water. It does not dissolve but on addition of luciferin gives a fair light.

Luciferase therefore is completely precipitated by basic lead acetate, nearly completely precipitated by neutral lead acetate, but not precipitated by mercuric chloride.

If a saturated solution of $\mathrm{HgCl}_{2}$ is added drop by drop to luciferin solution a precipitate forms. If this is filtered off, washed with dilute $\mathrm{HgCl}_{2}$, and suspended in water, it does not completely dissolve but gives a good light if an excess of luciferase is added. The opalescent filtrate which gives no further precipitate with $\mathrm{HgCl}_{2}$ gave a fair light on adding an excess of luciferase. Mercuric chloride and acetic acid almost completely precipitate luciferin from solution.

Neutral lead acetate solution added to luciferin gives a heavy precipitate. The solution filters cloudy at first even though no further precipitate forms on adding lead acetate, but soon filters clear. This clear filtrate containing some $\mathrm{Pb}$ gives a bright light on addition of excess of luciferase. The precipitate was washed several times on the filter and by decantation with dilute $\mathrm{Pb}$ acetate, and suspended in water. It does not completely dissolve but gives a good light with luciferase. Lead acetate and acetic acid give no good precipitate with crude luciferin. 
Basic lead acetate gives a voluminous heavy precipitate with crude luciferin. After heating, the solution was filtered and the clear filtrate, which gave no further precipitate with basic lead acetate, gave a brilliant light with luciferase. The precipitate washed twice with water on the filter does not dissolve in water, but suspended in water gives a faint light on adding luciferase. Uranium nitrate + acetic acid does not completely precipitate luciferin from solution. These results are recorded in Table III.

Luciferin is therefore not completely precipitated from solution by mercuric chloride with or without acetic acid, neutral lead acetate or basic lead acetate, or uranium nitrate and acetic acid.

\section{Acids and Alkalies.}

As alkalies $\left(\mathrm{KOH}\right.$ or $\mathrm{NaOH}$ in small, $\mathrm{NH}_{4} \mathrm{OH}$ in greater concentration) precipitate the $\mathrm{Mg}$ of sea water, this salt should be removed from a crude solution of luciferin and luciferase before studying the precipitating effects of the substances. This can be done by the addition of a small amount of sodium pyrophosphate which forms $\mathrm{Ca}$ and $\mathrm{Mg}$ pyrophosphates insoluble in water. The precipitates are removed by filtration and the photogenic substances are found unharmed by the addition of pyrophosphate.

Neither luciferin nor luciferase is precipitated by addition of dilute $\mathrm{NaOH}$ or dilute $\mathrm{NH}_{4} \mathrm{OH}$ to their crude solutions, first rendered free of $\mathrm{Ca}$ and $\mathrm{Mg}$.

Dilute acetic acid added to luciferase solution gives a fine precipitate which is filtered off and washed with running water for 24 hours. It does not dissolve completely in water and gives only a faint light with luciferin. The precipitate is probably a mucin and carries down some adsorbed luciferase. The filtrate is perfectly clear, gives no further precipitate (sometimes a slight cloudiness on standing) with acetic acid, but a bright light with luciferin. The addition of slightly more acetic acid results in a clear filtrate giving no light with excess luciferin. The precipitate on the filter does give a faint light with excess luciferin but appears to be injured by the acid.

Saturation with $\mathrm{CO}_{2}$ causes a precipitation in crude luciferase solution, but the filtrate gives a brilliant light with luciferin. 
Dilute acetic acid added to concentrated luciferin gives a stringy precipitate. If filtered off, the filtrate is slightly opalescent but does not become more cloudy or precipitate if more acetic acid is added. It gives a bright light if luciferase is added to it. The precipitate does not completely dissolve in water, but if washed with water and suspended in water gives a fair light with luciferase. This precipitate is probably a mucin containing some adsorbed luciferin. In the luminous gland of Cypridina there is a material which stains as does mucin and it would be found in the hot water extract of the whole animal. The acetic acid precipitate does not form readily if the luciferin solution is hot when acetic acid is added. A little dilute $\mathrm{NH}_{4} \mathrm{OH}$ will dissolve the precipitate and it can be reprecipitated by acetic acid. The filtrate from the acetic acid precipitation gives a voluminous precipitate with phosphotungstic acid which does not carry down all the luciferin unless a little $\mathrm{HCl}$ is also added, when luciferin is completely precipitated and may be demonstrated in the precipitate.

Dilute $\mathrm{HCl}$ alone gives a precipitate with crude luciferin solution but it almost completely dissolves in an excess of dilute $\mathrm{HCl}$.

Saturation of a solution of crude luciferin in presence of some $\mathrm{NaCl}$ with carbon dioxide does not cause precipitation or an increase in turbidity.

Dilute trichloroacetic acid gives a stringy precipitate with crude luciferin solution similar to that with acetic acid, but abundant luciferin is found in the clear filtrate which gives no further precipitate with trichloroacetic acid. These results are recorded in Table III.

Hence neither luciferin nor luciferase is precipitated from crude solution by dilute $\mathrm{NH}_{4} \mathrm{OH}$ or $\mathrm{NaOH}$ or by dilute acetic acid, and neither of them can belong to the group of histones (precipitated by dilute $\mathrm{NH}_{4} \mathrm{OH}$ ) or mucins, or nucleoproteins, or such phosphoproteins as caseinogen, which are precipitated by dilute acetic acid. A mucin or nucleoprotein is precipitated from both crude luciferase and luciferin solution by dilute acid and carries down some luciferase and some luciferin in the adsorbed state. It is easy to demonstrate that such an adsorption might occur. A solution of sodium caseinogenate mixed with either luciferin or luciferase and precipitated with acetic acid will carry down a considerable amount, but not all of the luciferin 
or luciferase. Luciferin is not, but luciferase is injured by an excess of dilute acetic acid.

Dubois $^{5}$ reports that Pholas luciferin is not precipitated by carbonic acid in neutal solutions or by acetic acid except in presence of neutral salts and that it forms an insoluble alkali albuminate with $\mathrm{NH}_{4} \mathrm{OH}$. The latter is possibly a $\mathrm{Mg}(\mathrm{OH})_{2}$ formed from the magnesium in the luciferin solution.

\section{Adsorbents.}

Proteins are usually separated from their solutions by one or another of the following methods: heat coagulation (in trace of acid); precipitation by alcohol or acetone (in large excess); precipitation by heavy metal salts (basic lead acetate, $\mathrm{HgCl}_{2}$ and acid, uranium acetate and acid, etc.); alkaloidal reagents (phosphotungstic, tannic, picric acids, etc.); salting out (by $\mathrm{MgSO}_{4}$ and acid, $\left(\mathrm{NH}_{4}\right)_{2} \mathrm{SO}_{4}$, etc.) ; digestion by proteolytic enzymes; adsorption (by chloroform, toluene, $\mathrm{Fe}(\mathrm{OH})_{3}$, kaolin, and gum mastic).

We have already noted the behavior of luciferase and luciferin toward the first six methods. Both of these substances can also be separated from solution by adsorption on appropriate material; in fact, they are rather readily adsorbed especially by inorganic precipitates. Their complete adsorption is usually merely a matter of obtaining sufficient adsorbing surface area. For this reason comparative studies on adsorption of different materials are difficult to carry out because we cannot be sure of uniform surface area. However, it may be of interest to record a few of the experiments on adsorption.

A neutral dilute solution of luciferase was found to be completely adsorbed by bone-black, $\mathrm{Fe}(\mathrm{OH})_{3}, \mathrm{As}_{2} \mathrm{~S}_{3}$, infusorial earth $\left(\mathrm{SiO}_{2}\right)$, talc, and kaolin; nearly completely adsorbed by asbestos, pumice, $\mathrm{CaCO}_{3}$, and $\mathrm{MgCO}_{3}$; not nearly completely adsorbed by ground glass, sulfur powder, gelatin or agar-agar threads, heat-coagulated egg albumin, fresh precipitated caseinogen, cotton, or cornstarch.

A solution of luciferase shaken with five successive additions of fresh chloroform, until the chloroform is no longer emulsified but separates as readily as with water, is reduced considerably in luciferase content but the luciferase is not completely removed by the chloroform. 
Neutral luciferin is completely adsorbed by bone-black, $\mathrm{Fe}(\mathrm{OH})_{3}$, kaolin, talc, and $\mathrm{CaCO}_{3}$, but not by many organic precipitates as caseinogen, cornstarch, or gelatin threads. There is the difficulty in studying adsorption of luciferin that oxidation may be accelerated by the presence of finely divided material.

Luciferin can also be removed practically completely from solution by gum mastic according to the method of Michaelis and Rona ${ }^{11}$ for removing proteins from blood serum.

\section{CONCLUSIONS.}

There seems to be very little doubt but that luciferase is a protein or so closely associated with proteins that their removal destroys its characteristic properties. The particular group of proteins to which it belongs may be arrived at by a process of exclusion, and only the group of albumins has properties which agree completely with those of luciferase.

Dubois believes Pholas luciferase to be an oxidizing enzyme similar to the oxydones of Battelli and Stern ${ }^{12}$ because it is readily destroyed by fat solvents such as chloroform, strong alcohol, etc. He has detected iron in a luciferase solution which has dialyzed against running water for a long time, and believes it to be made up of protein in combination with iron and to act as an "oxyzymase ferrique." Cypridina luciferase, on the other hand, is not readily destroyed by fat solvents. Toluene and chloroform are good preservatives, and I often make use of them for this purpose, keeping the luciferase solutions for many months. Professor A. H. Phillips of Princeton University has very kindly analyzed some whole dried Cypridina for me and finds iron, copper, and manganese but no zinc or vanadium to be present. Whether these metals are connected with the action of Cypridina luciferase is uncertain, but it is significant that all three of the metals thought to be concerned in organic oxidations are present.

Although a large amount of luciferin mixed with a small amount of

${ }^{11}$ Michaelis, L., and Rona, P., Biochem. Z., 1907, ii, 219; Rona and Michaelis, ibid., 1907, iii, 109; Michaelis and Rona, ibid., 1907, iv, 11.

${ }^{12}$ Battelli, F., and Stern, L., Biochem. Z., 1914, lxvii, 443. 
luciferase will use up all the latter,,$^{13}$ I agree with Dubois that luciferase has sufficient properties in common with the enzymes as a class to be considered an enzyme. The peroxidases are well known to be used up in the reactions they accelerate. All workers on enzymes agree that the more enzymes are purified the less active they become. The chemical procedures necessary to remove foreign material bring about irreversible changes in the enzyme itself, a characteristic also of many protein groups and of the colloidal state in general. This is true in the case of luciferase, for the crude luciferase solution is the most active preparation that can be obtained.

I believe that Cypridina luciferase should be placed in a class of oxidizing enzymes by itself--a group having the chemical reactions of an albumin, possibly in combination with some heavy metal, and which as far as we know, acts specifically on only one substance, Cypridina luciferin. It resembles the plant peroxidases in resisting the action of chloroform, toluene, etc., but will not oxidize any of the hydroxyphenol or aminophenol compounds ${ }^{14}$ so readily oxidized by the

${ }^{13}$ If concentrated luciferin and weak luciferase are mixed, the light which appears will last a long time before going out. After the light disappears, if this mixture is diluted with water or more luciferin is added, no further luminescence occurs, but if more weak luciferase is added, light again is produced and lasts a considerable time. The fact that no more light appears on diluting the concentrated luciferin-weak luciferase mixture with water shows that the enzyme has not been inhibited by reaction products. If so, the dilution of these reaction products should allow the system to proceed to a new (false) equilibrium with production of light. Dubois (Ann. Soc. Linn. Lyons, 1917, Ixiv, 105) has misunderstood my previous statement regarding this.

${ }^{14}$ Because of the ease with which many of these hydroxyphenyl compounds undergo autooxidation, one must always compare the color produced by luciferase solution with that produced in a control of boiled luciferase solution. I find that a concentrated luciferase solution well shaken with chloroform and filtered, which produced a brilliant light with luciferin, had no oxidative action on phenol, $\alpha$-naphthol, p-phenylenediamine, ortol, orcinol, hydrochinon, resorcinol, pyramidon, phloroglucin, pyrocatechol, gallic acid, benzidine, pyrogallol, gum guaiac, amidol, tannin, or $\alpha$-naphthylamine, either with or without $\mathrm{H}_{2} \mathrm{O}_{2}$. Dubois (Ann.Soc. Linn. Lyons, 1914, xli, 161) reports oxidation of pyrogallol, tannin, hydroquinone, guaiacol, Tromsdrof reagent, chlorohydrate of diaminophenol, $p$-phenylenediamine, and naphthol, naphthol $\mathrm{B}$, and gum guaiac plus $\mathrm{H}_{2} \mathrm{O}_{2}$ by a solution of Pholas luciferase. These results are of little value, however, as there is no evidence that the oxidation is due to luciferase rather than the oxidizing enzymes which one finds in cell extracts of all animals whether luminous or nonluminous. 
peroxidases, nor will the peroxidases oxidize luciferin with light pro duction. Dubois' researches show that Pholas luciferase differs in some properties from Cypridina luciferase, and my own work ${ }^{15}$ indicates that firefly luciferase is more like that of Pholas. A comparative study of other species of luminous animals is needed in order to delimit more accurately the class of luciferases as a whole.

Luciferin presents many characteristics in common with the proteins, but two, which, to say the least, throw doubt on its protein nature: (1) its peculiar solubility (in alcohols, esters, and glacial acetic acid), (2) and its resistance to digestion by proteases, even by trypsin which has almost universal digestive action. These two peculiarities have been discussed above. We can only say that if a protein, luciferin must belong to a new group differing from known natural proteins in these respects. In general characteristics this new group would fall somewhere on the border-line between the proteoses and peptones. It would not be surprising to find in nature proteoses or peptones soluble in absolute alcohol. We know also that some NH-CO linkages of proteins are broken down with great difficulty by trypsin as it is difficult to obtain a tryptic digest of protein which does not give the biuret reaction, and the work of Fischer and Abderhalden has shown that certain artificial polypeptides are not digested by pure activated pancreatic juice. We have, then, three possibilities. Luciferin is (1) either a natural proteose not attacked by trypsin, or (2) if attacked by trypsin, its decomposition products (presumably amino-acids) still contain the group oxidizable with light production, or (3) it is not a protein at all. I believe that luciferin has too many protein characteristics to conform to the last possibility. I have been unable to oxidize with light production various mixtures of amino-acids (from beef and casein) by means of luciferase and consequently am led to believe that luciferin is a new natural proteose, soluble in absolute alcohol and not digested by trypsin.

Dubois believes Pholas luciferin to be a natural albumin with acid properties. Cypridina luciferin could not possibly be regarded as an albumin, but it is very likely that the luciferins of different species of luminous animals differ in certain characteristics. As in the case of

${ }^{15}$ Harvey, Am. J. Physiol., 1917, xlii, 342. 
the luciferases, we know that the luciferins are not identical substances, and only future work can determine in what particulars they differ.

A summary of the properties of Cypridina luciferin and Cypridina luciferase will be found in the tables accompanying this paper. 